Research Article

\title{
Pogonatherumol, a Novel Highly Oxygenated Norsesquiterpene with Flavone C-Glycosides from Pogonatherum crinitum
}

\author{
Lin Ni, ${ }^{1,2}$ Wei Huang, ${ }^{2}$ He-shan Wang, ${ }^{3}$ and Hui-you Xu $\mathbb{C}^{1}$ \\ ${ }^{1}$ College of Plant Protection, Fujian Agriculture and Forestry University, Fuzhou 350002, China \\ ${ }^{2}$ Fujian Colleges and University Engineering Research Institute of Conservation \& Utilization of Natural Bioresources, \\ Fujian Agriculture and Forestry University, Fuzhou 350002, China \\ ${ }^{3}$ College of Pharmacy, Fujian University of Traditional Chinese Medicine, Fuzhou 350108, China
}

Correspondence should be addressed to Hui-you Xu; huiyouxu@126.com

Received 12 June 2018; Revised 23 July 2018; Accepted 31 July 2018; Published 23 August 2018

Academic Editor: Gabriel Navarrete-Vazquez

Copyright (C) 2018 Lin Ni et al. This is an open access article distributed under the Creative Commons Attribution License, which permits unrestricted use, distribution, and reproduction in any medium, provided the original work is properly cited.

\begin{abstract}
A novel highly oxygenated norsesquiterpene, pogonatherumol (1), with two known flavone C-glycosides (2-3), was isolated from Pogonatherum crinitum. The structure of the new compound was illuminated based on its spectroscopic data and X-ray analysis. Compounds 1 and 3 inhibited NO production in the mouse peritoneal macrophage $(64.5 \pm 7.2 \%$ and $61.6 \pm 5.8 \%$, respectively, at a concentration of $50 \mu \mathrm{M})$. The three compounds were inactive when tested against two human cancer cell lines $\left(\mathrm{IC}_{50}\right.$ values $\left.>50 \mu \mathrm{M}\right)$.
\end{abstract}

\section{Introduction}

Pogonatherum crinitum, is one of the species in the genus Pogonatherum of Gramineae family, which has been used as a natural medicine in Chinese folk [1], for treatment of diabetes, urinary tract infection, jaundice hepatitis, and nephritis [2-5]. Previous phytochemical studies on this plant have led to a series of flavones and lignins, some of which showed anti-inflammatory and antifungal activities $[6,7]$. In order to discover structurally and biologically interesting compounds from $P$. crinitum, a novel highly oxygenated norsesquiterpene, pogonatherumol (1) with two known flavone C-glycosides was investigated (Figure 1). Herein, the isolation and structural characterization of the compounds and their biological activities are reported in this paper.

\section{Experimental}

2.1. General Experimental Procedures. X-ray dif-segment intensity data of $\mathbf{1}$ were collected on an MAC DIP-2030K diffractometer with graphite-monochromated Mo $\mathrm{K} \alpha$ radiation and were corrected by Lorentz and polarization. An XT-5B micromelting point apparatus was used to determine the melting point. JEOL ECZ-400S, JASCO V-650, and Nicolet iS5N spectrophotometers manufactured by Thermo Scientific were used to record NMR, UV, and IR spectra, respectively. Thermo Scientific LTQ Orbitrap XL was used to collect HRESIMS spectra. Column chromatography (CC) was performed with silica gel (300400 mesh), polyamide (60-100 mesh), Sephadex LH-20, D101 macroporous, and ODS $(50 \mu \mathrm{m})$. Preparative HPLC made up for an LC-20AP instrument, an SPD-20A detector, and an ODS-A column (YMC, $250 \times 20 \mathrm{~mm}, 5 \mu \mathrm{m}$ ) was used to purify the compounds.

2.2. Plant Material. Pogonatherum crinitum was collected in Jianyang, Fujian, China, in September 2015. Professor Xiaoxing Zou, from the Fujian Agriculture and Forestry University (FAFU), People's Republic of China (PRC), identified the plant. The plant specimen was deposited at the lab of the material basis and utilization of TCM, College of Plant Protection, FAFU, PRC. 


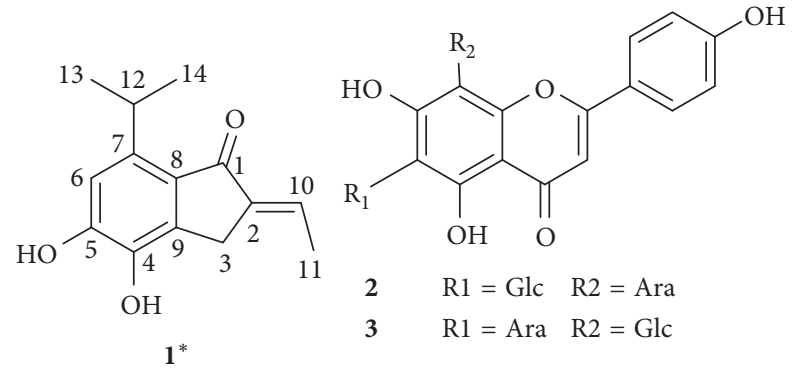

Figure 1: The structure of compounds 1-3. *New compound.

2.3. Extraction and Isolation. Air-dried and powdered herba of Pogonatherum crinitum $(10 \mathrm{~kg}$ ) was heated under reflux two times with $75 \%$ aqueous EtOH $(80 \mathrm{~L} \times 2 \mathrm{~h} \times 2)$ at $80^{\circ} \mathrm{C}$. The extract was evaporated under reduced pressure, and the residue was suspended in $\mathrm{H}_{2} \mathrm{O}$ and then extracted with EtOAc $(8 \mathrm{~L} \times 3)$. The ethyl acetate segment (113.2 g) was dissolved in water and subjected to passage over polyamide eluting with $\mathrm{H}_{2} \mathrm{O}$ and $50 \%$ EtOH- $\mathrm{H}_{2} \mathrm{O}(\mathrm{v} / \mathrm{v})$, successively (segments $\mathrm{A}_{1}$ and $\mathrm{A}_{2}$ ). The $50 \%$ EtOH-water extract (segment $\mathrm{A}_{2}, 43.7 \mathrm{~g}$ ) was passed over $\mathrm{CC}$ on silica gel eluting with $\mathrm{CH}_{2} \mathrm{Cl}_{2}-\mathrm{MeOH}(15: 1-1: 1)$ to afford 8 segments $\left(B_{1}-B_{8}\right)$. Segment $B_{3}(1.032 \mathrm{~g})$ was subjected to passage over Sephadex LH-20 eluting with $\mathrm{MeOH}$ and finally purified by preparative HPLC to give $\mathbf{1}(23 \mathrm{mg})$, using chromatographic condition as $\mathrm{MeOH}-\mathrm{H}_{2} \mathrm{O}(30: 70, \mathrm{v} / \mathrm{v})$, and detected at $210 \mathrm{~nm}$, $8 \mathrm{~mL} / \mathrm{min}$. Segment $\mathrm{B}_{5}(5.273 \mathrm{~g})$ was subjected to passage over an RP-18 column with $\mathrm{MeOH}-\mathrm{H}_{2} \mathrm{O}(15 \%, 30 \%$, and $45 \%$, v/v, successively) to afford 3 segments $\left(\mathrm{C}_{1}-\mathrm{C}_{3}\right)$. Finally, segment $\mathrm{C}_{2}$ $(1.518 \mathrm{~g})$ was purified by preparative HPLC to give $2(10 \mathrm{mg})$ and 3 (8 mg), under chromatographic condition as $\mathrm{MeCN}-\mathrm{H}_{2} \mathrm{O}(15$ : $85, \mathrm{v} / \mathrm{v})$, and detected at $210 \mathrm{~nm}, 8 \mathrm{~mL} / \mathrm{min}$.

2.3.1. Pogonatherumol (1). Colorless needles; mp $153^{\circ} \mathrm{C}$ $154^{\circ} \mathrm{C}$; UV $(\mathrm{MeOH}) \lambda_{\max }(\log \varepsilon) 232(3.53) \mathrm{nm}$; IR $\nu_{\max } 3313$, 2960, 2867, 1672,1566, 1510,1294,1182, 922, $866 \mathrm{~cm}^{-1} ;{ }^{1} \mathrm{H}$ NMR (DMSO- $d_{6}, 400 \mathrm{MHz}$ ) and ${ }^{13} \mathrm{C}$ NMR (DMSO- $d_{6}$, $100 \mathrm{MHz}$ ) (Table 1); HRESIMS $m / z 233.11728[\mathrm{M}+\mathrm{H}]^{+}$ (calcd. for $\mathrm{C}_{14} \mathrm{H}_{17} \mathrm{O}_{3}, 233.12722$ ).

2.3.2. Crystallographic Data of 1. Bond precision: $\mathrm{C}-\mathrm{C}=0.0059$; wavelength $=0.71073$; cell: $a=8.214$ (4), $b=$ 6.783 (3), $c=22.236$ (11); alpha =90; beta =90; gamma =90; temperature: $296 \mathrm{~K} ; \mathrm{C}_{14} \mathrm{H}_{16} \mathrm{O}_{3}, \mathrm{Mr} 232.27$; space group Pnma; hall group-p2ac2n; Dx $=1.245 \mathrm{~g} \cdot \mathrm{cm}^{-3} ; 1.092 \mathrm{~g} \cdot \mathrm{cm}^{-3}$, $F(000)=496 ; \mathrm{Mu}=0.087 \mathrm{~mm}^{-1} ; \quad \mathrm{nref}=1607 ; T_{\min }=0.468$, $T_{\max }=0.746 ; \quad$ data completeness $=0.982 ; \quad$ theta $(\max )=$ 28.149; $\mathrm{R}$ (reflections $)=0.0888(946) ; \quad$ WR2 $($ reflections $)=$ 0.2143(1607); $s=1.130 ;$ npar $=114$.

The crystallographic data of the structure of pogonatherumol (deposition number: CCDC 1842928) were deposited at the Cambridge Crystallographic Data Centre.

2.4. Biological Activities. Two cell lines, human ovarian neoplasm cell (A2780) and human colon cancer cell line (HCT-116), were used to test the tumor cytotoxic activities, and Taxol was used as a positive control. The method was
TABle $1:{ }^{1} \mathrm{H}$ and ${ }^{13} \mathrm{C}$ NMR data of compound $\mathbf{1}$.

\begin{tabular}{lcc}
\hline Number & $\delta_{\mathrm{c}}^{\mathrm{a}}$ & $\begin{array}{c}\delta_{\mathrm{H}}^{\mathrm{b}} \\
\text { (mult. J/Hz) }\end{array}$ \\
\hline 1 & 191.5 & - \\
2 & 138.7 & - \\
3 & 26.1 & $3.43, s$ \\
4 & 139.1 & - \\
5 & 151.0 & - \\
6 & 112.1 & $6.76, s$ \\
7 & 142.1 & - \\
8 & 126.7 & - \\
9 & 137.7 & - \\
10 & 129.5 & $6.56, d(7.1)$ \\
11 & 14.8 & $1.89, d$ (7.1) \\
12 & 26.2 & $4.06, m$ \\
13 & 23.2 & $1.12, d(6.8$, overlap) \\
14 & 23.2 & $1.12, d(6.8$, overlap) \\
\hline
\end{tabular}

${ }^{\mathrm{a}}$ In DMSO- $d_{6}(100 \mathrm{MHz}) ;{ }^{\mathrm{b}}$ in DMSO- $d_{6}(400 \mathrm{MHz})$.

according to the previously described [8]. LPS-induced RAW264.7 macrophage was used to evaluate the NO production inhibition activity of the three compounds. Dexamethasone was used as a positive control, and the test method was according to the literature $[9,10]$.

\section{Results and Discussion}

Pogonatherumol (1) was obtained as colorless needles $(\mathrm{MeOH})$. The IR spectrum of $\mathbf{1}$ showed 3313, 1672, and $1566 \mathrm{~cm}^{-1}$ absorption bands, which were assigned to hydroxyl, carbonyl, and olefin functionalities, respectively. The molecular formula was determined to be $\mathrm{C}_{14} \mathrm{H}_{16} \mathrm{O}_{3}$ on the basis of HRESIMS (an $[\mathrm{M}+\mathrm{H}]^{+}, m / z 233.11728$ ), which corresponded to the molecular formula, indicating 7 degrees of unsaturation. Analysis of the ${ }^{1} \mathrm{H}$ NMR spectroscopic data of 1 (Table 1) revealed three methyls $\left(\delta_{\mathrm{H}} 1.12,1.12\right.$ (3H each, both $d$, $\left.J=6.8 \mathrm{~Hz}, \mathrm{H}_{3}-13,14\right)$, and $\left.1.89\left(3 \mathrm{H}, d, J=7.1 \mathrm{~Hz}, \mathrm{H}_{3}-11\right)\right)$, a methylene $\left(\delta_{\mathrm{H}} 3.43(2 \mathrm{H}, s, \mathrm{H}-3)\right)$, an aromatic proton $\delta_{\mathrm{H}} 6.76$ $(1 \mathrm{H}, s, \mathrm{H}-6)$, an olefin proton $\delta_{\mathrm{H}} 6.56(1 \mathrm{H}, m, \mathrm{H}-10)$, and two hydroxyls $(10.06(1 \mathrm{H}, s)$ and $8.74(1 \mathrm{H}, s))$. And the ${ }^{13} \mathrm{C} \mathrm{NMR}$ (Table 1) and DEPT spectra showed fourteen carbons, including a carbonyl, a methene, three methines, three methyls, and six aromatic carbons, two of them bearing oxygen atoms (C-4 and C-5). HMBC correlations of H-6/C-4, C-5, and C-8; $\mathrm{H}-3 / \mathrm{C}-1, \mathrm{C}-2$, C-8, and C-9; 4-OH/C-5 and C-9; and 5-OH/C$4, \mathrm{C}-5$, and C-6 confirmed the presence of the indanone skeleton (Figure 2). An isopropyl $\left(\delta_{\mathrm{H}} 1.12,1.12\right.$ (3H each, both $\left.d, J=6.8 \mathrm{~Hz}, \mathrm{H}_{3}-13,14\right)$ and $\left.4.06(1 \mathrm{H}, m, \mathrm{H}-12)\right)$ was attached to $\mathrm{C}-7$, which could be confirmed by the HMBC correlation from $\mathrm{H}-13$ and $\mathrm{H}-14$ to $\mathrm{C}-12$ and $\mathrm{C}-7$ and from $\mathrm{H}-12$ to $\mathrm{C}-6$, C-7, and C-8. Further HMBC correlations of H-11/C-10 and $\mathrm{C}-2$ and of $\mathrm{H}-10 / \mathrm{C}-1$ indicated that an ethylidene was fixed in $\mathrm{C}-2$, and NOESY correlation from $\mathrm{H}_{3}-11$ to $\mathrm{H}-3$ suggested the trans-configuration of double bonds between C-2 and C-10 (Figure 2). Finally, the proposed structure of 1, (E)-2ethylidene-4,5-dihydroxy-7-isopropyl-2,3-dihydro-1H-inden1-one, named "pogonatherumol" was confirmed by an X-ray crystallography analysis. The ORTEP drawing, with the atomnumber scheme indicated, is shown in Figure 3. 


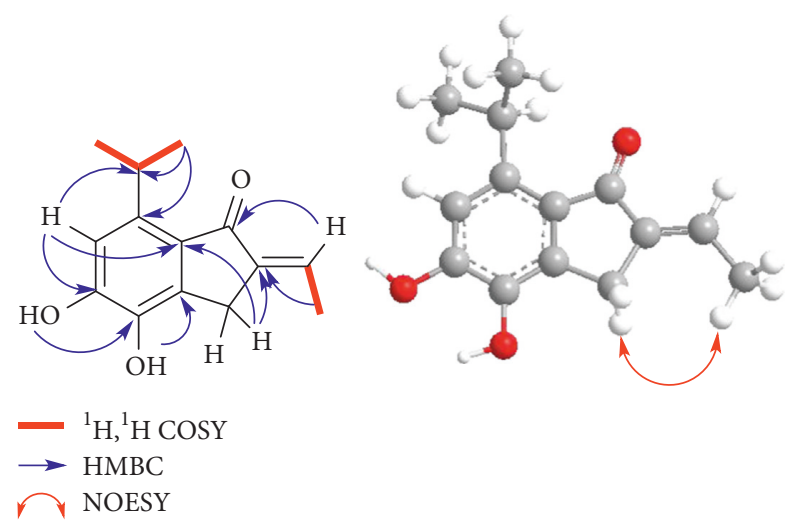

Figure 2: Key ${ }^{1} \mathrm{H},{ }^{1} \mathrm{H}$ COSY, HMBC, and NOESY correlations of $\mathbf{1}$.

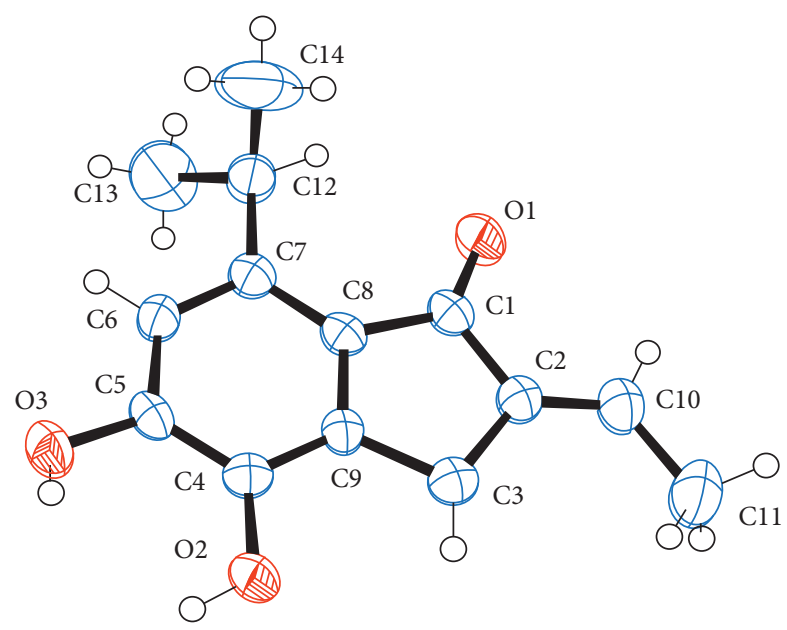

FIgURE 3: ORTEP drawing of compound 1.

In addition to pogonatherumol, two known C-glycosides, schaftoside (2) [11] and isoschaftoside (3) [12], were identified by comparing their ESIMS and ${ }^{1} \mathrm{H}$ and ${ }^{13} \mathrm{C}$ NMR data with those reported in the literature.

Pogonatherumol (1) with a fused indanone skeleton has not been previously reported as a natural product. Notably, it seems to be a novel rearrangement of norsesquiterpene.

Meanwhile, the inhibited NO production and the tumor cytotoxic activities of three compounds were evaluated. Compounds 1 and 3 inhibited NO production in the mouse peritoneal macrophage $(64.5 \pm 7.2 \%$ and $61.6 \pm 5.8 \%$, respectively, at a concentration of $50 \mu \mathrm{M}$ ), while the positive control dexamethasone gave an inhibitory ratio of 59.4.1 \pm $6.2 \%$ at a concentration of $10 \mu \mathrm{M}$. All compounds were also evaluated in vitro for cytotoxicity against A2780 and HCT-116 cell lines employing an MTT assay with Taxol as the positive control. The three compounds were inactive when tested against the two human tumor cell lines $\left(\mathrm{IC}_{50}\right.$ values $\geq 50 \mu \mathrm{M})$.

\section{Data Availability}

The data used to support the findings of this study are available from the corresponding author upon request.

\section{Conflicts of Interest}

The authors declare that there are no conflicts of interest.

\section{Acknowledgments}

This work was supported by the National Natural Science Foundation of China (no. 31700292).

\section{Supplementary Materials}

The supplementary materials contain HRESIMS, IR, and NMR spectra of compound $\mathbf{1}$ and NMR data of compounds 2 and 3. (Supplementary Materials)

\section{References}

[1] T. Huang, Z. Ding, and X. Zhao, Modern Compendium of Materia Medica, China Medical Science Press, Beijing, China, 2001.

[2] Z. Yi, D. Gao, H. Wang, and G. Zhao, "Study on the chemical constituents of Pogonatherum crinitum," China Journal of Experimental Traditional Medical Formulae, vol. 20, pp. 104-107, 2014.

[3] G. Chen, X. Li, Z. Shi, and G. Zhao, "Study on the fat-soluble chemical constituents from Pogonatherum crinitum," Journal of Chende Medical College, vol. 27, pp. 216-218, 2010.

[4] G. Zhao, L. Liu, X. Mao, and J. Dong, "Flavonol glycosides from Pogonatherum crinitum," Chinese Journal of New Drugs, vol. 20, pp. 467-470, 2011.

[5] D. Zhu, J. Yang, M. Lai, and Q. Wang, "A new C-glycosylnavone from Pogonatherum crinitum," Chinese Journal of Natural Medicines, vol. 8, no. 6, pp. 411-413, 2010.

[6] G. Wang, Y. Chen, T. Wang, C. Lee, K. Chen, and T. Lee, "Flavonoids with iNOS inhibitory activity from Pogonatherum crinitum," Journal of Ethnopharmacology, vol. 118, pp. 71-78, 2008.

[7] S. Lei, L. Ni, X. Wu et al., "Study on anti-fungal constituents of Pogonatherum crinitum," Chinese Journal of Pesticide Science, vol. 19, pp. 119-124, 2017.

[8] X. Zheng, J. Yang, J. Lv et al., "Phyllaciduloids A-D: four new cleistanthane diterpenoids from Phyllanthus acidus (L.) skeels," Fitoterapia, vol. 125, pp. 89-93, 2018.

[9] J. Ren, Y. Xie, Y. Guo, S. Zhu, H. Jin, and W. Zhang, "Unusual metal complex of cadinane sesquiterpene alkaloid and new neolignan glycosides from Alangium alpinum," Fitoterapia, vol. 125, pp. 18-23, 2018.

[10] L. Ni, L. Li, Y. Qiu et al., "Nerolidol-type sesquiterpene glucosides from the leaves of Tripterygium wilfordii," Fitoterapia, vol. 128, pp. 187-191, 2018.

[11] C. Mao, S. Li, Q. Xu, and S. Yang, "Chemical constituents in stems of Ilex cornuta," Chinese Traditional and Herbal Drugs, vol. 47, pp. 891-896, 2016.

[12] S. Li, "Chemical constituents of Arisaema rhizomatum," Journal of Chinese Pharmaceutical Sciences, vol. 49, no. 17, pp. 1503-1505, 2014. 

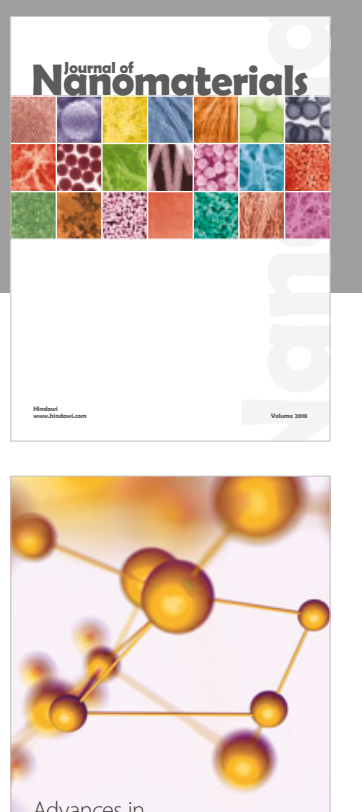

Physical Chemistry
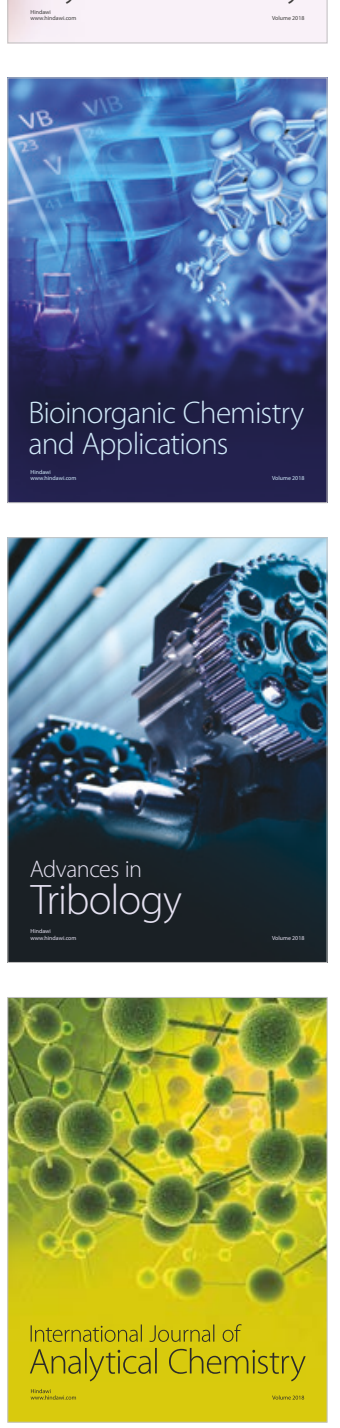

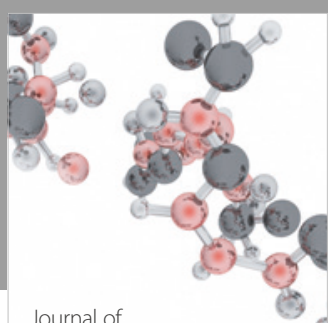

Analytical Methods

in Chemistry

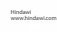

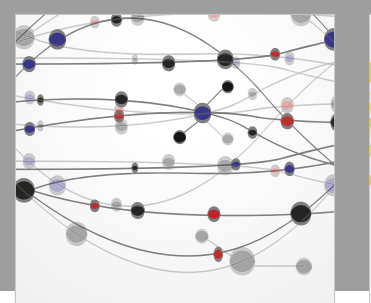

The Scientific World Journal

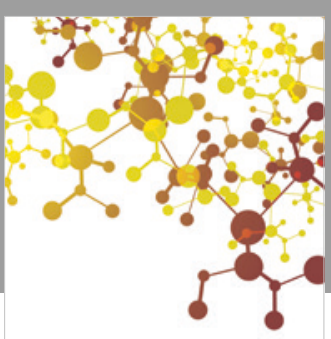

Journal of

Applied Chemistry
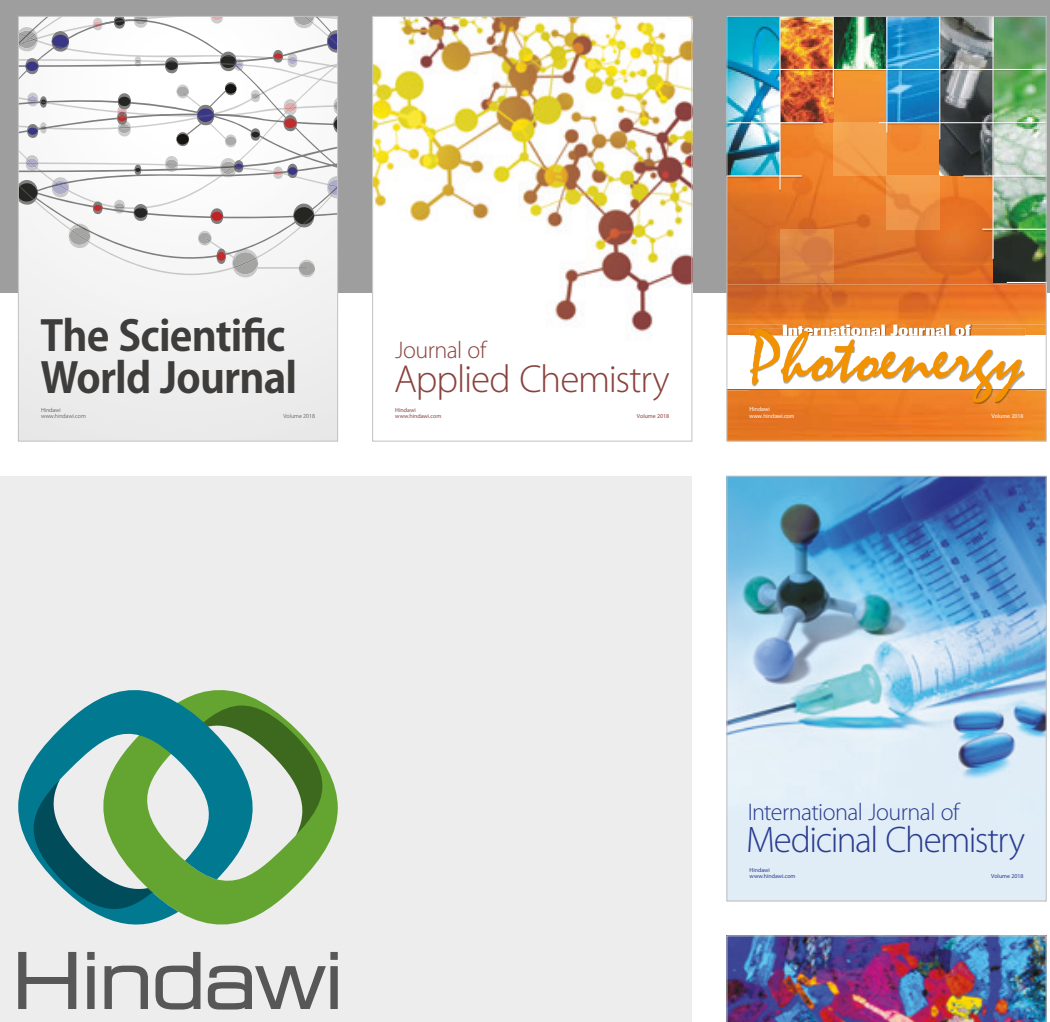

Submit your manuscripts at

www.hindawi.com
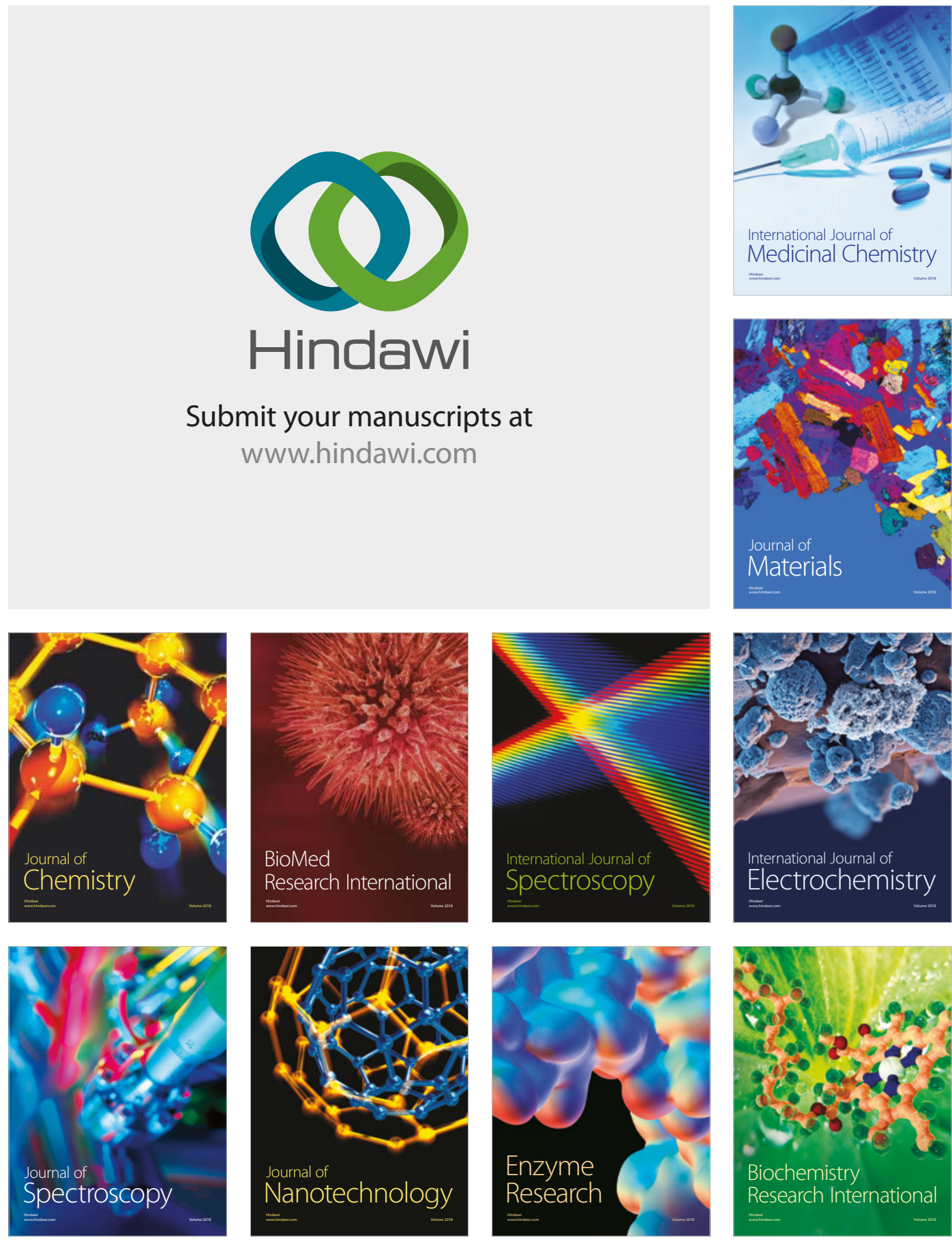
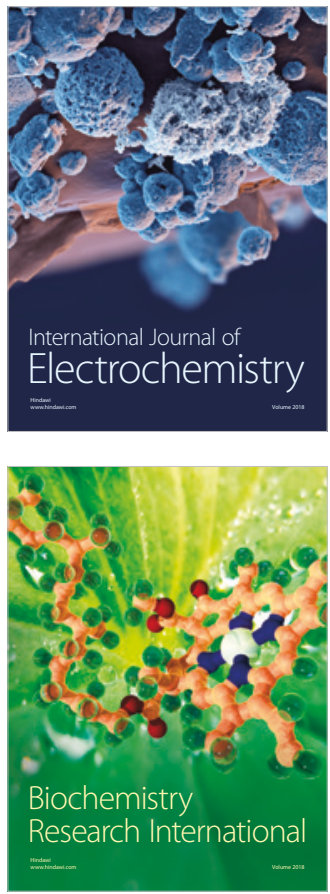